\title{
Editorial
}

\section{Paul Hurley}

This special issue of Philosophical Studies consists of a selection of papers, symposia, and Author-Meets-Critics sessions presented at the 2009 meeting of the Pacific Division of the American Philosophical Association. Members of the 200809 Program Committee chose the papers for presentation and offered recommendations for publication. The members of that committee are:

Paul Hurley (Chair)

Richard Arneson

Mohammad Azadpur

Sylvia Berryman

Craig Callender

Rebecca Copenhaver

Branden Fitelson

Patrick R. Frierson

Peter Graham

Nadeem J. Z. Hussain

Eric Hutton

Sherri Irvin

Robin Jeshion

Amy Kind
Mark McPherran

Dana Nelkin

Ryan Nichols

Jay Odenbaugh

Laurie Paul

Mary V. Rorty

Patrick W. Rysiew

David Schmidtz

Amy Schmitter

Charles Siewert

Ori Simchen

Julie Tannenbaum

Iain Thomson

Eric Watkins

P. Hurley (两)

Claremont McKenna College, 850 Columbia Ave., Claremont, CA 91711, USA

e-mail: Paul.Hurley@claremontmckenna.edu 